\title{
Effect of planting techniques and weed control treatments on growth and yield of wheat
}

\author{
Sudesh Devi $^{1}$, V.S. Hooda ${ }^{1 *}$, Jagdev Singh ${ }^{1}$ and Anil Kumar ${ }^{2}$ \\ ${ }^{1}$ Department of Agronomy, CCS Haryana Agricultural University, Hisar-125004 (Haryana), INDIA \\ ${ }^{2}$ Department of FM\&PE, CCS Haryana Agricultural University, Hisar-125004 (Haryana), INDIA \\ *Corresponding author. E-mail: vshooda79@gmail.com
}

Received: October 5, 2016; Revised received: March 4, 2017; Accepted: July 31, 2017

\begin{abstract}
A field experiment was conducted to study the effect of different planting techniques (conventional drill sowing at 16, 18 and $20 \mathrm{~cm}$ row spacing and bed planting with two and three rows in main plots) and weed control treatments (pinoxaden $50 \mathrm{~g} / \mathrm{ha}$, ready-mix (RM) of carfentrazone and metsulfuron $25 \mathrm{~g} / \mathrm{ha}$ and pinoxaden $50 \mathrm{~g} / \mathrm{ha}+$ $\mathrm{RM}$ of carfentrazone and metsulfuron $25 \mathrm{~g} / \mathrm{ha}$ in subplots) on growth and productivity of wheat. The grain yield under row spacing $18 \mathrm{~cm}(53.30 \mathrm{q} / \mathrm{ha})$, and $20 \mathrm{~cm}(52.02 \mathrm{q} / \mathrm{ha})$, and three rows bed planting $(51.96 \mathrm{q} / \mathrm{ha})$ were recorded statistically at par with each other and significantly higher than $16 \mathrm{~cm}(49.37 \mathrm{q} / \mathrm{ha})$ row spacing and two row bed planting (48.53 q/ha). Gross returns (Rs. 95637/ha) and net returns (Rs. 43929/ha) and B:C ratio (1.85) were recorded higher under $18 \mathrm{~cm}$ row spacing compared to other planting techniques. Tank mixed application of pinoxaden 50 $\mathrm{g} / \mathrm{ha}+\mathrm{RM}$ of carfentrazone and metsulfuron $25 \mathrm{~g} / \mathrm{ha}$ applied at 35 days after sowing (DAS) controlled both grassy and broad leaved weeds effectively with lower values of weed dry matter accumulation (7.67 g/ha) and produced growth parameters, yield attributes and yield $(53.16 \mathrm{q} / \mathrm{ha})$ at par with weed free treatment. In light of the results to maximise productivity, $18 \mathrm{~cm}$ row spacing may be practiced and tank mix application of pinoxaden (50 g/ha) + RM of carfentrazone and metsulfuron ( $25 \mathrm{~g} / \mathrm{ha})$ is recommended to reduce losses due to complex weed flora in wheat.
\end{abstract}

Keywords: Growth, Planting techniques, Weed control, Wheat, Yield

\section{INTRODUCTION}

Wheat (Triticum aestivum L.) is one of the three most important cereals cultivated worldwide. In India, it is the second most cultivated staple food crop after rice and grown on an area of 30.47 million hectares with total production of 95.85 million tonnes and productivity of $3146 \mathrm{~kg} / \mathrm{ha}$ in 2013-14 (Agricultural Statistics at a glance, 2015). Many fold increase in production of wheat (since independence) is mainly attributed to increase in area under production and green revolution through adoption of high yielding varieties and improved package and practices. However, the yield growth rate of major cereals including wheat is showing a declining trend since last few years. Wheat yields gains have slowed to only $1.1 \%$ per annum in India (Ray et al., 2013).

Rising demographic pressure has made it necessary to augment the productivity of food crops including wheat on continues basis to ensure food security (Swaminathan and Bhavani, 2013). This can be achieved by efficient use of resources with improved practices and technologies with minimum possible environmental damage. Establishment of optimum plant density by manipulating row spacing is one of several important agronomic approaches that can be used to enhance wheat yield. (Thorsted et al., 2006;
Hussain et al., 2013; Naresh et al., 2014).

Raised bed planting has been found to improve water distribution and water use efficiency (Idnani and $\mathrm{Ku}-$ mar, 2012). Permanent raised beds add the opportunity for direct drilling of crops in the system, with related benefits including rapid turnaround between crops and reduced tillage costs and greenhouse gas emissions. Bed planting provide opportunity for mechanical weeding and improved fertilizer placement, increase fertilizer use efficiency, reduce water logging, soil erosion, irrigation water saving, reduced salinity stress, opportunities for intercropping, reduce weed infestation and increased crop yield (Ghane et al., 2011; Kumar et al., 2013; Naresh et al., 2014; Bhujel et al., 2015; Dey et al., 2015; Gul et al., 2015; Singh et al., 2016).

Wheat field is generally infested with both types of weeds viz. grassy as well as broad leaved causing severe competition for essential nutrients, moisture and space thus reducing wheat yield (Chhokar et al., 2012; Chopra et al., 2015). Wheat yield can be reduced even up to $80 \%$ due to heavy infestation of weeds, depending upon weed type, density, timing of emergence, crop density, cultivar, soil and environmental factors (Chhokar and Malik, 2002). Among different methods of weed management, weed control using herbicides is 
preferred owing to cost and time effectiveness (Chhokar et al., 2012). However, sole dependence on herbicides with single mode of action is also not desirable due to evolution of herbicide resistance in weeds (Chhokar et al., 2012). As the introduction of herbicides with new mode of action has slowed down, therefore, there is need to use mixture of existing herbicides in a way to improve weed control efficacy and control complex and dynamic weed flora in wheat (Yadav et al., 2016).

For efficient weed management, the non-chemical weed management tactics should also be adopted in conjunction with chemicals. For example, agronomic strategies like tillage, sowing methods, higher crop density, closer spacing can be adjusted and adopted in such a manner that they provide the competitive edge to the crop over weeds (Chhokar et al., 2012; Bhullar et al., 2012). Integration of knowledge of nonchemical methods of weed control with chemical methods will help in increasing the life of existing herbicides and make the weed management costeffective and efficient. This study was therefore planned to evaluate the effects of various planting techniques and herbicide mixtures on weed dynamics, growth parameters, yield attributes and yield of wheat.

\section{MATERIALS AND METHODS}

A field experiment was conducted at Agronomy Research Farm of CCS Haryana Agricultural University, Hisar during Rabi season, 2012-13. Soil of the experimental field was sandy loam in texture, slightly alkaline in reaction, low in organic carbon $(0.33 \%)$ and available nitrogen $(182.4 \mathrm{~kg} / \mathrm{ha})$, medium in available phosphorus $(13.3 \mathrm{~kg} / \mathrm{ha})$ and high in available potassium $(365.3 \mathrm{~kg} / \mathrm{ha})$. Soil texture was determined by international pipette method (Piper, 1966), $\mathrm{pH}$ by Glass electrode $\mathrm{pH}$ meter (Jackson, 1973), organic carbon by Walkley and Black's rapid titration method (Walkley and Black, 1934), available nitrogen by alkaline permanganate method (Subbiah and Asija, 1956), available phosphorus by Olsen's method (Olsen et al., 1954) and available potassium by flame photometric method (Jackson, 1958). The experiment was laid out in a split -plot design with five planting techniques [conventional drill sowing at $20 \mathrm{~cm}\left(\mathrm{P}_{1}\right), 18 \mathrm{~cm}\left(\mathrm{P}_{2}\right)$ and $16 \mathrm{~cm}\left(\mathrm{P}_{3}\right)$, bed planting with three $\left(\mathrm{P}_{4}\right)$ and two rows $\left(\mathrm{P}_{5}\right)$ ] in main plot and five weed control treatments [pinoxaden $50 \mathrm{~g} / \mathrm{ha}\left(\mathrm{W}_{1}\right), \mathrm{RM}$ of carfentrazone and metsulfuron $25 \mathrm{~g} / \mathrm{ha}\left(\mathrm{W}_{2}\right)$, pinoxaden $50 \mathrm{~g} / \mathrm{ha}+$ $\mathrm{RM}$ of carfentrazone and metsulfuron $25 \mathrm{~g} / \mathrm{ha}\left(\mathrm{W}_{3}\right)$, weed free $\left(\mathrm{W}_{4}\right)$ and weedy check $\left.\left(\mathrm{W}_{5}\right)\right]$ in subplots with three replications. In bed planting, field was prepared as per conventional methods followed by preparation of beds which were $67.5 \mathrm{~cm}$ wide $(37.5 \mathrm{~cm}$ bed top and $30 \mathrm{~cm}$ furrow) with the help of bed planter. Wheat $c v$ ' $W H 711$ ' was seeded on $10^{\text {th }}$ December,
2012 with tractor drawn wheat seeding drills using 125 $\mathrm{kg}$ seeds/ha. Recommended doses of nitrogen $(\mathrm{N})$ and phosphorus (P) were applied through urea and diammonium phosphate (DAP), respectively. Full dose of $P$ and half dose of $\mathrm{N}$ were applied at sowing time and remaining $\mathrm{N}$ was applied with first irrigation. Herbicides were applied as post-emergence at 35 days after sowing (DAS) with the help of knapsack sprayer fitted with flat-fan nozzle using 500 liter of water/ha. The experimental data was statistically analyzed by the methods of analysis of variance (ANOVA) as described by Panse and Sukhatme (1985).

\section{RESULTS AND DISCUSSION}

Effect of planting techniques: Various planting techniques (conventional drill sowing at 16, 18 and $20 \mathrm{~cm}$ row spacing and bed planting with two and three rows) did not significantly influence the plant height of wheat in all growth stages of crop (Table 1). Pandey et al. (2013) in their study reported that plant height was not affected significantly by row spacing $(15,20$ and $25 \mathrm{~cm}$ ) in wheat. Significantly lower dry matter accumulation was recorded under conventional drill sowing of wheat at $16 \mathrm{~cm}$ at all crop growth stages as compared to all other planting techniques which were at par with each other (Table 1). Highest dry matter accumulation was observed under conventional drill sowing of wheat at $18 \mathrm{~cm}$ at all crop growth stages. This might be due to availability of more nutrients and moisture to plants under wider spacing. This indicates that narrow spacing escorts more inter row competition among the plants as compared to wider row spacing. Mali and Choudhary (2013) reported that among different row spacings $(15,17.5,20$ and $22.5 \mathrm{~cm}), 20 \mathrm{~cm}$ row spacing registered maximum dry matter accumulation which was at par with $22.5 \mathrm{~cm}$ row spacing and significantly higher over 17.5 and $15 \mathrm{~cm}$ in wheat.

For all planting techniques, leaf area index (LAI) increased progressively up to 90 DAS and then began to decline with dying of lower leaves (Table 1). Significantly lower LAI was recorded under conventional drill sowing of wheat at $16 \mathrm{~cm}$ at all crop growth stages as compared to all other planting techniques (Table 1). The efficient use of available resources resulted in higher LAI value under wider row spacing, whereas inter-row competition resulted in lower LAI value in $16 \mathrm{~cm}$ row spacing. In contrary to our results, Idnani and Kumar (2012) reported taller plant height and higher value of LAI under FIRBS (with three rows) over flat planting in wheat.

In general, numbers of tillers were recorded highest at 60 DAS and, thereafter, started to decline till harvest (Table 2). At all crop growth stages, significantly higher numbers of tillers were recorded under drill sowing with $18 \mathrm{~cm}$ row spacing as compared to other planting techniques. Bed planting with two and three rows recorded lesser number of tillers as compared to drill sow- 
Sudesh Devi et al. / J. Appl. \& Nat. Sci. 9 (3): 1534 -1539 (2017)

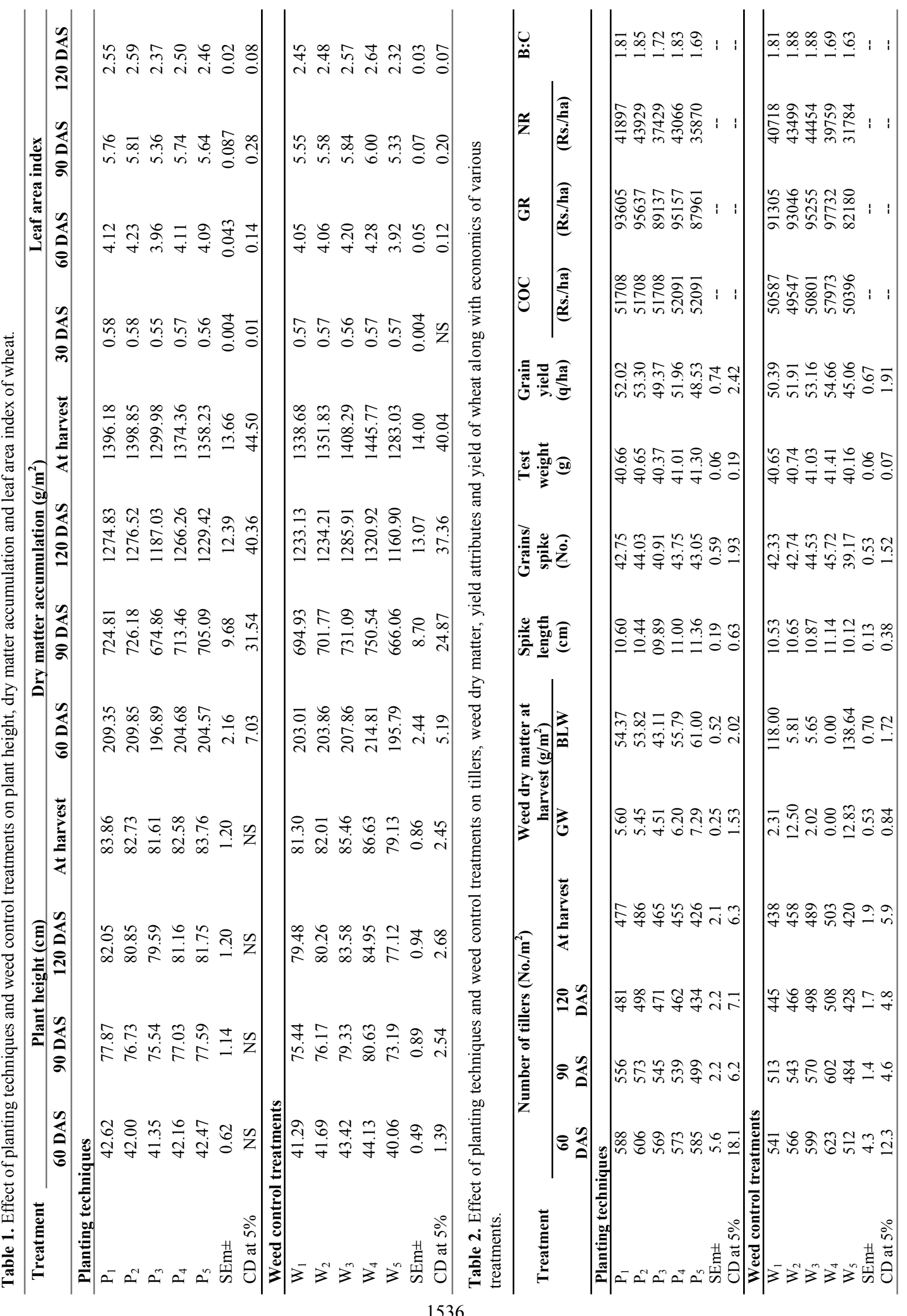


ing with row spacing of $16 \mathrm{~cm}, 18 \mathrm{~cm}$ and $20 \mathrm{~cm}$ except at 60 DAS. Drill sowing with $16 \mathrm{~cm}$ row spacing recorded minimum number of tillers among all planting techniques at 60 DAS. Among bed planting methods, tillers were recorded significantly higher under three rows bed planting as compared to two row bed planting at all crop growth stages except at 60 DAS. As the crop was sown late, it attained its full tillering capacity at $60 \mathrm{DAS}$, and then tillers declined due to mortality as a result of increased competition among the tillers. The higher number of tillers under conventional methods as compared to bed planting has been reported by Kaur et al. (2001). Bed planting with two rows of wheat showed maximum decrease in tillers from 60 to 90 DAS as compared to other techniques. This might be due to overcrowding of tillers within a single row because uniform seed rate was used in all planting techniques. While in other planting methods the maximum mortality was recorded from 90 to 120 DAS.

The dry matter accumulation for both grassy and broad leaved weeds was highest under bed planting with two rows of wheat and lowest under drill sowing with 16 $\mathrm{cm}$ row spacing (Table 2). The dry matter accumulation for both grassy and broad leaved weeds under drill sowing with 18 and $20 \mathrm{~cm}$ row spacing and bed planting with three rows were statistically at par with each other. Narrow spacing provided less space for weeds to grow; thereby increasing competitive potential of crop. Lesser dry matter accumulation by weeds under closer row spacing in wheat compared to wider row spacing has also been reported by Mahajan and Brar (2001). Walia et al. (2003) reported lesser dry weight accumulation by weeds in drill sowing with narrow rows as compared to other planting methods like bed planting with two and three rows.

Bed planting with two rows recorded significantly longer spike as compared to all other planting techniques, but was at par with bed planting with three rows (Table 2). Conventional drill sowing at $16 \mathrm{~cm}$ row spacing recorded lowest spike length not only with respect to row spacing of 18 and $20 \mathrm{~cm}$ but also with respect to bed planting with three and two rows. Significantly lesser number of grains per spike was recorded under conventional drill sowing of wheat at 16 $\mathrm{cm}$ at as compared to all other planting techniques which remained at par with each other (Table 2). Test weight was recorded highest under bed planting with two rows of wheat followed by bed planting with three rows of wheat as compared to other planting techniques viz. drill sowing with different row spacing like 16,18 and $20 \mathrm{~cm}$ (Table 2). The drill sowing with 16 $\mathrm{cm}$ row spacing recorded significantly lower test weight as compared to all other planting techniques. Drill sowing at narrow spacing $(16 \mathrm{~cm})$ produced significantly shorter spike length, lesser number of grains per spike and test weight as compared to all other planting techniques due to more competition for resources among densely populated plants. Walia et al. (2003) reported higher spike length and 1000 grains weight for bed planting with two rows as compared to bed planting with three rows and drill sowing. Yield attributes viz. earhead length and 1000 grain weight were recorded significantly higher under FIRBS (with three rows) as compared to conventional sowing in wheat by Idnani and Kumar (2012).

Conventional drill sowing of wheat at $18 \mathrm{~cm}$, being at par with drill sowing at $20 \mathrm{~cm}$ and bed planting with three rows, recorded significantly higher grain yield of wheat as compared to conventional drill sowing at 16 $\mathrm{cm}$ and bed planting with two rows which remained at par with each other (Table 2). Substantial increase in yield-related traits like effective tillers, grains per spike, spike length and test weight may be attributed to the efficient utilization of resources like light, water, nutrients etc. Mali and Choudhary (2013) in their study on wheat reported that, among different row spacings $(15,17.5,20$ and $22.5 \mathrm{~cm}), 20 \mathrm{~cm}$ row spacing gave significantly higher grain yield as compared to 17.5 and $15 \mathrm{~cm}$ row spacing and was at par with $22.5 \mathrm{~cm}$ row spacing. Despite of higher spike length and test weight, grain yield under two rows bed planting was lower as compared to three rows under bed planting and drill sowing at 16, 18 and $20 \mathrm{~cm}$ row spacing primarily due to significantly less number of tillers (Table 2).

The cost of cultivation under bed planting methods was recorded higher as compared to drill sowing methods (Table 2). Gross returns, net returns and B:C ratio were highest under conventional drill sowing with 18 $\mathrm{cm}$ row spacing, followed by bed planting with three rows of wheat. This indicates the efficient utilization of growth factors like water, nutrients and solar radiation by the crop under $18 \mathrm{~cm}$ row spacing. Minimum net returns and $\mathrm{B}: \mathrm{C}$ ratio were recorded under bed planting with two rows of wheat. Two rows bed planting was least economical due to lower yields and higher cost of production.

Effect of weed control treatments: At all crop growth stages, weed free plot recorded taller plants, higher dry matter accumulation, LAI and tillers compared to other herbicidal treatments (Table 1 and 2), which were found to be at par with tank mix application of pinoxaden $50 \mathrm{~g} / \mathrm{ha}+\mathrm{RM}$ of carfentrazone and metsulfuron 25 $\mathrm{g} / \mathrm{ha}$. The improvement in plant growth parameters due to combined application of pinoxaden + RM of carfentrazone and metsulfuron can be attributed to effective control of both grassy and broad leaved weeds. The control of grassy as well as broad leaved weeds provided enough space for crop growth and leaf expansion and hence higher value of LAI was recorded. Significantly lower plant growth parameters under weedy check were due to more competition offered by weed flora to the crop for resources like nutrient, moisture, 
space, sunlight etc and smothering effect of weeds on crop plants. Chopra et al. (2015) reported that yield attributes under application of tank mix of pinoxaden $(50 \mathrm{~g} / \mathrm{ha})+$ carfentrazone $(20 \mathrm{~g} / \mathrm{ha})$ and pinoxaden $(50$ $\mathrm{g} / \mathrm{ha})+$ metsulfuron $(4 \mathrm{~g} / \mathrm{ha})$ were at par and significantly higher than sole application of pinoxaden $(50 \mathrm{~g} /$ ha and $75 \mathrm{~g} / \mathrm{ha})$, carfentrazone (20 g/ha) and metsulfuron $(4 \mathrm{~g} / \mathrm{ha})$ in wheat crop.

The dry matter accumulation by grassy weeds at harvest was recorded highest in weedy check, which was at par with individual application of RM of carfentrazone and metsulfuron $25 \mathrm{~g} /$ ha (Table 2). This indicates the inefficiency of RM of carfentrazone and metsulfuron in controlling the grassy weeds. Application of pinoxaden $50 \mathrm{~g} / \mathrm{ha}$ alone and tank mixed with RM of carfentrazone and metsulfuron $25 \mathrm{~g} /$ ha resulted in significantly lower dry matter accumulation by grassy weeds as pinoxaden is effective in controlling the grassy weeds. The dry matter accumulation of broad leaved weeds at harvest was recorded highest in weedy check, which was at par with individual application of pinoxaden $50 \mathrm{~g} /$ ha (Table 2), because pinoxaden had poor control of broad leaved weeds. The tank mix application of pinoxaden $50 \mathrm{~g} / \mathrm{ha}+\mathrm{RM}$ of carfentrazone and metsulfuron $25 \mathrm{~g} /$ ha resulted in significantly lower dry matter accumulation by broad leaved weeds and was at par with individual application of RM of carfentrazone and metsulfuron $25 \mathrm{~g} / \mathrm{ha}$. This indicates that $\mathrm{RM}$ of carfentrazone and metsulfuron $25 \mathrm{~g} / \mathrm{ha}$ is effective in controlling broad leaved weeds. Shoeran et al. (2013) also reported the effective action of pinoxaden against grassy weeds but without any efficiency against broad leaved weeds. On the other hand, RM of carfentrazone and metsulfuron was very effective in controlling broad leaved weeds but inefficient in controlling the grassy weeds (Singh et al., 2011).

Among all weed control treatments, weed free plot recorded longest spike and highest number of grains per spike (Table 2); but was at par with tank mix application of pinoxaden $50 \mathrm{~g} / \mathrm{ha}+\mathrm{RM}$ of carfentrazone and metsulfuron $25 \mathrm{~g} / \mathrm{ha}$. Spike length and grains per spike under application of pinoxaden $50 \mathrm{~g} / \mathrm{ha}$ was statistically at par with RM of carfentrazone and metsulfuron $25 \mathrm{~g} / \mathrm{ha}$, but were significantly higher than weedy check. The test weight was highest under weed free plot and lowest under weedy check plot (Table 2). Tank mix application of pinoxaden $50 \mathrm{~g} / \mathrm{ha}+\mathrm{RM}$ of carfentrazone and metsulfuron $25 \mathrm{~g} /$ ha produced significantly better test weight than individual application of pinoxaden and RM of carfentrazone and metsulfuron. Weed control treatments decreases the competition of crop plants with weeds and led to efficient utilization of available resources and hence better yield attributes. Shoeran et al. (2013) also reported positive effect of herbicide mixtures on yield attributes of wheat.

All weed control treatments showed significant increase in grain yield over weedy check (Table 2).
Weed free treatment, being at par with tank mix application of pinoxaden $50 \mathrm{~g} / \mathrm{ha}+\mathrm{RM}$ of carfentrazone and metsulfuron $25 \mathrm{~g} / \mathrm{ha}$, registered significantly higher grain yield than all other treatments. Grain yields under individual application of pinoxaden $50 \mathrm{~g} / \mathrm{ha}$ and $\mathrm{RM}$ of carfentrazone and metsulfuron $25 \mathrm{~g} / \mathrm{ha}$ were at par with each other, however, significantly higher than weedy check. Higher yield with combined application of both types of herbicides can be attributed to improved growth and yield attributes which in turn can be attributed to better weed control and hence, efficient utilization of resources. Tank mix application of $\mathrm{Pi}$ noxaden + carfentrazone and pinoxaden + metsulfuron were found to be more effective in increasing grain yield of wheat compared to sole application of pinoxaden , carfentrazone and metsulfuron (Shoeran et al., 2013, Chopra et al., 2015, Katara et al., 2015).

Among all weed control treatments, highest gross returns were recorded under weed free, whereas highest net returns and $\mathrm{B}: \mathrm{C}$ ratio were recorded under tank mix application of pinoxaden $50 \mathrm{~g} / \mathrm{ha}+\mathrm{RM}$ of carfentrazone and metsulfuron $25 \mathrm{~g} /$ ha (Table 2). Higher net returns were due to higher grain yield and lower cost of production. However, gross returns was recorded maximum under weed free due to highest yield, but on account of more cost of cultivation (due to weeding) the net returns and $\mathrm{B}: \mathrm{C}$ ratio were significantly reduced. Chopra et al., 2015 reported that tank mix application of pinoxaden + carfentrazone (50 $\mathrm{g} / \mathrm{ha}+20 \mathrm{~g} / \mathrm{ha})$ and pinoxaden + metsulfuron $(50 \mathrm{~g} / \mathrm{ha}$ $+4 \mathrm{~g} / \mathrm{ha}$ ) in wheat gave higher net returns and $\mathrm{B}: \mathrm{C}$ ratio over sole application of pinoxaden $(50 \mathrm{~g} / \mathrm{ha})$, carfentrazone $(20 \mathrm{~g} / \mathrm{ha})$ and metsulfuron $(4 \mathrm{~g} / \mathrm{ha})$.

\section{Conclusion}

Different planting techniques had significant effects on the productivity of wheat. It can be concluded that, among different planting techniques, drill sowing at 18 and $20 \mathrm{~cm}$ and bed planting with three rows were better in terms of growth and yield ( $53.30 \mathrm{q} / \mathrm{ha}, 52.02 \mathrm{q} /$ ha, $51.96 \mathrm{q} /$ ha respectively) over $16 \mathrm{~cm}$ row spacing and two rows bed planting (49.37 q/ha, $48.53 \mathrm{q} / \mathrm{ha}$ respectively). Tank mix application of pinoxaden (50 $\mathrm{g} / \mathrm{ha})+\mathrm{RM}$ of carfentrazone and metsulfuron ( $25 \mathrm{~g} / \mathrm{ha})$ at 35 DAS was found to be more remunerative and effective herbicide mixture than application of pinoxaden (50 g/ha) alone and RM of carfentrazone and metsulfuron $(25 \mathrm{~g} / \mathrm{ha})$ at 35 DAS for control of complex weed flora in wheat.

\section{ACKNOWLEDGEMENTS}

We are thankful to Department of Agronomy, College of Agriculture, CCS Haryana Agriculture University, Hisar for providing infrastructural facilities.

\section{REFERENCES}

Agricultural Statistics at a Glance (2015). Directorate of 
Economics and Statistics, Ministry of Agriculture, Govt. of India (Website: http://www.dacnet.nic.in/ eands).

Bhujel, B., Moinuddin and Lepcha, S. (2015). Influence of weed management practices and irrigation schedules under different establishment methods on performance of field pea (Pisum sativum L. arvense). Int. J. Curr. Res. Aca. Rev. 3: 52-60.

Bhullar, M.S., Shergill, L.S., Kaur, R., Walia, U.S. and Kaur, T. (2012). Bioefficacy of herbicides in relation to sowing methods in wheat. Indian J. Weed Sci. 44: 214-217.

Chhokar, R. S., Sharma, R. K. and Sharma, I. (2012). Weed management strategies in wheat-A review. J. Wheat Res. 4: 1-21.

Chhokar, R.S. and Malik, R.K. (2002). Isoproturon-resistant littleseed canary grass (Phalaris minor) and its response to alternate herbicides. Weed Technol. 16: 116-123.

Chopra, N. K., Chopra, N. and Choudhary, D. (2015). Bioefficacy of sole and tank-mix of pinoxaden and clodinafop with carfentrazone and metsulfuron for control of complex weed flora in wheat (Triticum aestivum). Indian J. Agron. 60: 104-108.

Dey, D., Nath, D. and Jamatia, P. B. (2015). Effect of raised bed planting method of maize under sandy loam soil of west Tripura. Int. J. Appl. Res.1: 561-563.

Ghane, E., Mostafazadeh-Fard, B., Feizi, M. and Landi, E. (2011). Effect of water quality and different planting methods on wheat yield. Commun. Soil Sci.Plan. 42: 369-380

Gul, S., Khan, M. H., Khanday, B. A. and Nabi, S. (2015). Effect of Sowing Methods and NPK Levels on Growth and Yield of Rainfed Maize (Zea mays L.). Hindawi Publishing Corporation Scientifica (Website: http:// dx.doi.org/10.1155/2015/198575).

Hussain, M., Khan, M.B., Mehmood, Z., Zia, A.B., Jabran, K. and Farooq M. (2013). Optimizing row spacing in wheat cultivars differing in tillering and stature for higher productivity. Arch. Agron. Soil Sci. 59: 14571470.

Idnani, L.K. and Kumar, A. (2012). Relative efficiency of different irrigation schedules for conventional, ridge and raised bed seeding of wheat (Triticum aestivum). Indian J. Agron. 57: 148-151.

Jackson, M. L. (1973). Soil chemical analysis. Prentice Hall of India Pvt. Ltd. New Delhi. pp. 183-192.

Jackson, M.L. (1958). Soil chemical analysis. Prentice Hall of India Pvt. Ltd., New Delhi. pp. 187

Katara, P., Kumar, S. and Rana, S. S. (2015). Influence of pinoxaden in combination with other herbicides on nutrient deplation by weeds in wheat. Indian J. Weed Sci. 47: 371-375.

Kaur, G., Kler, D.S., Singh, S., Kaur, G. and Singh, S. (2001). Relationship of height, lodging score and silica content with grain yield of wheat (Triticum aestivum L.) under different planting techniques at higher nitrogen nutrition. Environ. Ecol. 19: 412-417.

Kumar, V., Kumar, P. and Singh, R. (2013). Growth and yield of rice-wheat cropping sequence in raised bed planting system. Indian J. Agric. Res. 47: 157-162.

Mahajan, G. and Brar, L.S. (2001). Integrated management of Phalaris minor in wheat. Indian J. Weed Sci. 33: 9 13.

Mali, H. and Choudhary, J. (2013). Performance of bread wheat (Triticum aestivum L.) varieties under different row spacing. J. Wheat Res. 4: 55-57.

Naresh, R. K., Tomar, S. S., Purushottam, Singh, S. P., Kumar, D., Pratap, B., Kumar, V. and Nanher, A. H. (2014). Testing and evaluation of planting methods on wheat grain yield and yield contributing parameters in irrigated agro-ecosystem of western Uttar Pradesh, India. African J. Agric. Res. 9: 176-182.

Olsen, S.R., Cole, C.V., Watanabe, F.S. and Dean, L.A (1954). Estimation of available phosphorus in soils by extraction with sodium bicarbonate. USDA Circulation, 939.

Pandey, B.P., Basnet, K.B., Bhatta, M.R., Sah, S.K., Thapa, R.B. and Kandel, T.P. (2013). Effect of row spacing and direction of sowing on yield and yield attributing characters of wheat cultivated in western Chitwan, Nepal. Agr. Sci. 4: 309-316.

Panse, V.G. and Sukhatme, R.V. (1985). Statistical methods for agricultural workers $4^{\text {th }}$ Ed. ICAR, New Delhi.

Piper, C.S. (1966). Soil and plant analysis; Hans Publishers, Bombay.

Ray, D. K., Mueller, N. D., West, P. C. and Foley, J. A. (2013). Yield trends are insufficient to double global crop production by 2050, San Francisco (CA): Public Library of Science (PLOS), volume 8(6); |cited 2017, Feb 27|. Available from: http:/www.plosone.org/article/ info\%3Aoi\%2F10.1371\%2Fjournal.pone.0066428.

Shoeran, S., Punia, S.S., Yadav, A. and Singh, S. (2013). Bioefficacy of pinoxaden in combination with other herbicides against complex weed flora in wheat. Indian J. Weed Sci. 45: 90-92.

Singh, C. B., Hashim, M., Kumar, A., Rishi Raj and Pandey, U. C. (2016). Performance of improved wheat (Triticum aestivum) varieties under various planting techniques in north eastern plain zone of India. J. Community Mobilization Sustain. Dev. 11: 145-149.

Singh, S., Punia, S.S., Yadav, A. and Hooda, V.S. (2011). Evaluation of carfentrazone - ethyl + metsulfuron methyl against broadleaf weeds of wheat. Indian $J$. Weed Sci. 43: 12-22.

Subbiah, B.V. and Asija, A.K. (1956). A rapid procedure for the estimation of available nitrogen in soil. Curr. Sci. 24: $259-260$

Swaminathan'M. S. and Bhavani, R. V. (2013). Food production \& availability - Essential prerequisites for sustainable food security. Indian J. Med. Res. 138: 383391.

Thorsted, M.D., Olesen, J.E. and Weiner, J. (2006). Width of clover strips and wheat rows influence grain yield in winter wheat/white clover intercropping. Field Crop Res. 95: 280-290.

Walia, U.S., Brar, L.S. and Jand, S. (2003). Integrated effect of planting methods and herbicides on Phalaris minor and wheat. Indian J. Weed Sci. 35: 169-172.

Walkley, A.J. and Black, C.A. (1934). Estimation of soil organic carbon by the chromic acid titration method. Soil Sci. 37: 29-38.

Yadav, D. B., Yadav, A., Punia, S. S. and Chauhan, B. S. (2016). Management of herbicide-resistant Phalaris minor in wheat by sequential or tank-mix applications of pre- and post-emergence herbicides in north-western Indo-Gangetic Plains. Crop Prot. 89: 239-247. 